Published in final edited form as:

Curr Opin HIV AIDS. 2019 July ; 14(4): 318-324. doi:10.1097/COH.0000000000000556.

\title{
Neutralizing antibodies for HIV-1 prevention
}

\author{
Boris Julg ${ }^{1,2}$, Dan H Barouch ${ }^{1,2}$ \\ ${ }^{1}$ Ragon Institute of MGH, MIT and Harvard, 400 Technology Sq, Cambridge MA 02139 \\ ${ }^{2}$ Center for Virology and Vaccine Research, Beth Israel Deaconess Medical Center, 330 Brookline \\ Avenue, Boston, MA 02215
}

\begin{abstract}
Purpose of review-In the absence of a protective vaccine against HIV-1, passive immunization using novel broadly neutralizing antibodies (bNAbs) is an attractive concept for HIV-1 prevention. Here, we summarize the results of pre-clinical and clinical studies of bNAbs, discuss strategies for optimizing bNAb efficacy and lay out current pathways for the development of bNAbs as prophylaxis.
\end{abstract}

Recent findings-Passive transfer of second generation bNAbs results in potent protection against infection in preclinical animal models. Furthermore, multiple bNAbs targeting different epitopes on the HIV-1 envelope trimer are in clinical evaluation and have demonstrated favorable safety profiles and robust antiviral activity in chronically infected individuals. The confirmation that passive immunization with $\mathrm{bNAb}(\mathrm{s})$ will prevent HIV-1 acquisition in humans is pending and the focus of ongoing investigations. Given the global diversity of HIV-1, bNAb combinations or multi-specific antibodies will most likely be required to produce the necessary breadth for effective protection.

Summary-Encouraging results from preclinical and clinical studies support the development of bNAbs for prevention and a number of antibodies with exceptional breadth and potency are available for clinical evaluation. Further optimization of viral coverage and antibody half-life will accelerate the clinical implementation of bNAbs as a critical tool for HIV-1 prevention strategies.

\section{Keywords}

neutralizing antibodies; passive immunization; HIV prevention; global coverage of HIV-1 diversity

\section{Introduction}

Despite significant research efforts for over three decades, a protective vaccine against HIV-1 has been elusive. Alternative approaches for HIV-1 prevention are therefore necessary until a successful vaccine strategy is found. The idea of passive administration of neutralizing antibodies had been raised early on, however lack of efficacy using first

Correspondence to: Boris Julg, Dan Barouch, Center for Virology and Vaccine Research, Beth Israel Deaconess Medical Center, E/CLS - 1043, 330 Brookline Avenue, Boston, MA 02215, bjulg@mgh.harvard.edu; dbarouch@ bidmc.harvard.edu.

Conflicts of interest

The authors have no conflicts of interest. 
generation neutralizing antibodies (nAb) with limited potency and breadth dampened enthusiasm for this approach. With the introduction of reproducible high-throughput neutralization assays in combination with single B-cell receptor sequencing using HIV-1 envelope probes to sort HIV-1 specific B-cells $(1,2)$, a new generation of extremely potent and broadly neutralizing antibodies (bNAbs) was identified $(1,3,4)$. These new generation bNAbs are up to 100-fold more potent than the first-generation antibodies and exhibit significant neutralization breadth against cross-clade HIV-1 strains. Multiple antibodies against various sites of vulnerability on the HIV-1 envelope trimer have been described targeting the CD4-binding site of gp120, the V2-glycan site at the apex of the Env trimer, the V3-glycan site, the membrane-proximal external region (MPER) of gp41, and more recently the interface region between gp120 and gp41 (table 1) (reviewed in $(5,6)$ ). In the following review we will discuss the progress that has been made in evaluating the potential role of neutralizing antibodies in preventing HIV-1 infection and we will highlight obstacles and potential future avenues for bNAb development.

\section{Evidence of antibody protection in animal models}

Non-human primates (NHP), specifically infant and adult rhesus macaques, have been used to model natural HIV-1 transmission by mucosally challenging animals with a chimeric simian-human immunodeficiency virus (SHIV) which expresses HIV-1 envelope on a backbone of SIV. This model allows to quantify the protective efficacy of passively administered immunoglobulins by challenging the animals either with a single high dose of SHIV or repeated low dose challenges following administration of antibody(ies). Studies using this model have so far demonstrated varying degrees of protection, largely impacted by the neutralization sensitivity of the challenge stock to the administered antibodies (1722). Moldt et al demonstrated that the V3 glycan antibody PGT121 completely protected macaques against a high dose challenge with the tier 2 SHIV-SF162P3 at doses of $5 \mathrm{mg} / \mathrm{kg}$ and $1 \mathrm{mg} / \mathrm{kg}$ at antibody serum concentrations of $95 \mu \mathrm{g} / \mathrm{mL}$, and $15 \mu \mathrm{g} / \mathrm{mL}$ (23). Other potent bNAbs including VRC01, VRC07-523, 3BNC117 and 10-1074 have also demonstrated protection $(20,21,23,24)$ and PGDM1400 and CAP256-VRC26.25 protected animals against a clade C SHIV-325c challenge at doses of 0.4 (PGDM1400) and even 0.08 $\mathrm{mg} / \mathrm{kg}$ (CAP256-VRC26.25) with serum concentrations as low as $0.75 \mu \mathrm{g} / \mathrm{mL}$ (25). When comparing different bNAb/SHIV combinations in the NHP challenge model it has been suggested that plasma neutralization titers of $\sim 1: 100$ are required to prevent virus infection in 50\% of the exposed monkeys (20). A limitation of the model for testing human bNAbs is the dependence on SHIV strains that are sensitive to currently used bNAbs and the limited availability thereof, the lack of SHIV swarms to mimic HIV-1 diversity, and the relative low virulence of some of the SHIV strains used. Newer generations of SHIV strains, that share more similarities with HIV-1 and represent non-clade B envelopes have been and are getting developed and will hopefully expand the armamentarium for assessing bNAbs in passive transfer studies (26-28).

\section{Humanized mice}

Given the high costs associated with NHP studies and the constraints to the use of simian immunodeficiency viruses, humanized mouse models are getting employed to study HIV-1 
transmission. The presence of human hematopoietic and lymphoid cells in these animals support HIV-1 infection and enable the testing of bNAbs in-vivo against HIV-1. Some of the earlier studies to demonstrate the protective efficacy of nAbs and have been done in humanized mice (29) and protection by many newer generation bNAbs are assessed in this model (30-32). Incomplete immune reconstitution, e.g. limited formation of secondary lymphoid tissues and reduced levels and function of innate effector cells such as NK-cells however have been a limitation of the applicability of this model. In particular the ability to determine Fc-mediated antiviral functionality depends on sufficient availability of innate Fcreceptor expressing effector cells. Advances in generating humanized mice with more functional NK-cells (33) will allow for the dissection of functional properties of mAbs as shown by the enhanced clearance of infected cells by bNAbs, attributed to an Fc $\gamma \mathrm{R}$ dependent mechanism (34-36).

\section{Viral diversity}

In contrast to the single challenge virus NHP model, humans during natural HIV-1 transmission are exposed to viral swarms and one of the main challenges for bNAb based prevention strategies is the vast viral diversity observed in circulating HIV-1 strains. Ideally, the bNAb used for prevention would cover $100 \%$ of circulating strains however even the broadest bNAbs are not able to potently neutralize all HIV-1 strains. Wagh et al. recently determined the breadth and neutralization efficacy of antibody combinations against a panel of 200 clade C isolates (37) and the data suggest that at least three bNAbs will be necessary for preventing and treating HIV-1 infection. Indeed, the combination of PGT121 and PGDM1400 was required to protect macaques against a mixed SHIV challenge consistent of SHIV SF162P3, sensitive to PGT121 but not PGDM1400, and SHIV 325c with the opposite sensitivity pattern, while the administration of each antibody alone resulted in $100 \%$ breakthrough infection with the respective resistant SHIV strain (38). Efforts to increase viral coverage breadth are therefore ongoing which include the development of bispecific antibodies that target Env and an HIV-1 receptor or coreceptor and more recently Huang combined the MPER antibody 10E8 with iMab, the heavy-chain N-terminus of ibalizumab. $10 \mathrm{E} 8 / \mathrm{iMab}$ covered $100 \%$ of a 118 -virus panel with mean IC50 values of $0.002 \mu \mathrm{g} / \mathrm{mL}$ and protected hu-mice against HIV-1 $1_{\text {JR-CSF }}$ challenge (39). Combining 3 distinct Env epitope specificities, the VRC01/PGDM1400-10E8v4 trispecific antibody demonstrated excellent breadth and potency and conferred complete immunity against a mixture of SHIVs in nonhuman primates, in contrast to single bNAbs (40). A combination of two or more bNAbs, or engineered antibodies with multiple Fab specificities targeting multiple HIV-1 Env epitopes, is therefore most likely required to potently cover the entirety of the HIV-1 diversity $(37,41)$.

\section{Current status of bNAb studies in humans}

Over the past several years, there have been a series of studies that evaluated newer bNAbs including VRC01, 3BNC117, and 10-1074 for safety and tolerability in HIV uninfected individuals and also assessed antiviral efficacy in people living with HIV (42-45). Studies with the antibodies PGT121, PGDM1400, VRC07-523LS and N6LS are ongoing (NCT02960581, NCT03015181, NCT03205917, NCT03538626, NCT03735849, and 
NCT03015181). A study testing the safety of subcutaneous administration of the antibody 10E8V-LS (NCT03565315) was halted due to local reactogenicity. A study evaluating the antibody bNAb combinations 3BNC117 and 1010-74 showed favorable safety profiles (46) and other bNAb combination studies are currently ongoing using PGT121 and PGDM1400 or PGT121 and VRC07-523LS (NCT03205917 and NCT03721510). Studies testing engineered bi and tri-specific antibodies are currently under development. While no data about the protective efficacy of bNAbs against HIV-1 acquisition in humans is currently available, the AMP (antibody-mediated prevention) study consisting of two large randomized placebo-controlled trials is evaluating the protective effect of infusions with VRC01 every two months in women living in sub-Saharan Africa (HVTN 703/HPTN 081, NCT02568215) and in men and transgender persons who have sex with men (HVTN 704/ HPTN 085, NCT02716675). The results of the trials are expected soon. This study is critical as a proof-of-concept if passive immunization has the potential to protect against HIV-1 acquisition, however with the evidence from preclinical models suggesting that a single bNAb might not be sufficiently broad enough to neutralize a diverse virus exposure, evaluating the efficacy of bNAb cocktails or multi-specific antibodies will most likely be the logical next step in advancing antibodies as HIV-1 prevention strategy.

\section{Biodistribution of bNAbs}

Achieving and maintaining serum levels above a threshold concentration is a critical requirement for effective protection and necessitate that bNAbs are administered repeatedly. In the NHP-SHIV model, using challenge viruses that are highly sensitive against the tested $\mathrm{bNAb}$, protection can be achieved with serum concentrations in the range of 1-10 $\mu \mathrm{g} / \mathrm{ml}$ and even lower with some highly potent V2-apex antibody like CAP256-VRC26.25 $(23-25,47)$. One approach to extend the in-vivo half-life of the antibody serum concentrations has been the introduction of two amino acid mutations (M428느/N434 $\underline{\mathrm{S}}$ - LS) into the Fc-region to enhance binding to the neonatal $\mathrm{Fc}$-receptor $(\mathrm{FcRn})(48,49)$. This modification resulted in markedly extended period of protection in macaques using e.g. the antibodies 10-1074LS and 3BNC117LS (50) and many of the bNAbs that are under clinical evaluation are getting produced as LS variants. However, in addition to serum concentrations, bNAbs most likely will need to achieve sufficient mucosal and tissue concentrations to block infection prior to the virus' systemic distribution. bNAbs are found in mucosal secretions following IV administration suggesting that they are distributed systemically $(17,20,23)$. A study in infant macaque performing serial sacrifices to determine the kinetics of mAb tissue distribution detected polyclonal SIVIG but also monoclonal bNAbs across lymphoid tissues (51). Moreover, PGT121 mediated clearance of infection was observed in distal tissues in adult macaques following SHIV-SF162P3 challenge (52) suggesting i) the necessity for bNAbs to block infection beyond the mucosal surface but ii) that sufficient tissue levels were achieved following a single IV dose. While bNAbs seem to distribute into most organs, the low permeability of the blood-brain barrier restricts bNAb transfer into the central nervous system (CNS). It has been suggested that the CNS can harbor HIV-1 variants that are more resistant to bNAbs than what is detected in peripheral blood (53), however, this might be more of a concern for therapeutic approaches using bNAbs then for protection strategies. 


\section{Role of antibody effector functions in protection}

Data from NHP and humanized mice studies suggests that clearing infected cells in blood and tissues is part of the protective activity of bNAbs and required for preventing the systemic spread of infection $(34,52)$. Furthermore, a role for Fc-mediated effector function of antibodies in reducing transmitted founder viruses (54) or controlling post-infection viremia has been indicated in rhesus macaques (55-57). Lu et al demonstrated in the humanized mouse model, that upon binding to infected cells, the bNAb 3BNC117 could recruit Fc $\gamma \mathrm{R}$-dependent antibody-dependent cell-mediated phagocytosis (ADCP) and cytotoxicity (ADCC) and thereby was able to drive the elimination of infected CD4+ T cells (35). While it still needs to be shown if sterilizing protection can be achieved by functional but non-neutralizing antibodies, it has been suggested that Fc mediated anti-viral activities may augment the protective efficacy of neutralizing antibodies (58). Moreover, many studies have demonstrated strong correlations between serum titers of HIV-1 specific ADCC mediating antibodies and improved clinical outcomes $(59,60)$, e.g. HIV controller that maintain undetectable virus loads in the absence of antiretroviral therapy are enriched for polyfunctional antibodies (61). When poly-IgG from HIV controllers however was passively transferred to NHPs, no protection against SHIV challenge was observed, potentially due to the relative low quantity of the functional antibody within the total administered poly-IgG (62). In addition, efficacy of functional antibodies heavily relies on the availability of effector cells at the sites of HIV-1 transmission (63) and is affected by the affinity to Fc $\gamma$ Rs that differ between species (64). Non-neutralizing antibodies might also differ in their ability to bind to native Env trimers and monomeric structures compared to bNAbs (65) which might explain differences in the ability to mediate effective ADCC against infected cells (66). Given the importance of the Fc region for bNAbs to not only block infection but also clear infected cells, many Fc modifications, including Fc point mutations and Fc glycan variants are getting explored to enhance the FcyR binding and the induction of antiviral functions (67). Better understanding the bioactivity of the different $\mathrm{Fc}$ profiles that maximize protection against infection at different mucosal surfaces will be crucial for the successful and global implementation of bNAbs for prevention.

\section{Host immune modulation by bNAbs}

bNAb distribution into lymphoid tissues and co-localization with virus following systemic infection and potentially even just localized exposure enables the formation of immune complexes (ICs) and it has been postulated that these ICs could augment anti-viral immune response (68). Indeed, in HIV-1 infected individuals that were administered 3BNC117, expansion of autologous neutralizing antibody responses was reported (69) and the effect was more pronounced among subjects with detectable viremia. Early treatment of SIVinfected juvenile macaques with SIV-specific neutralizing IgG (SIVIG) accelerated NAb development by 20 weeks (70) and a second study confirmed that only SHIVIG highly specific for the challenge SHIV SF162P3, therefore retaining the ability to generate ICs, generated this effect (71). In addition to induction of humoral immunity, bNAb cocktail administration during acute SHIV infection of rhesus macaques resulted in 6/13 monkeys that maintained undetectable plasma HIV virus loads following bNAb clearance and CD8 Tcell depletion resulted in rapid reappearance of plasma viremia suggestive of a CD8 T-cell 
mediated effect of control (72). In contrast, a single dose of PGT121 or N6LS or a combination of both administered to chronically SHIV SF-162P3 infected macaques did not results in an increase in autologous neutralizing antibody titers above what was observed in the placebo control animals (73). Repeated 3BNC117 administration in humans before and during antiretroviral treatment interruption resulted in delayed viral rebound, however, HIV specific $\mathrm{T}$ cell magnitude and breadth did not seem to expand following bNAb infusion (74) with the caveat that there was no control group to compare T-cell responses to. The different aspects of the vaccinal effect of bNAb therapy are also discussed in a review by NaranjoGomez \& Pelegrin et al in this issue (...).

\section{Future: other isotypes and engineered mAbs}

While IgGs dominate the current development pipeline for monoclonal bNAbs, other isotypes have interesting features that suggest them as potential alternatives for antibodybased prevention strategies. IgM, recognized as the first responder to pathogens, execute high avidity/affinity to their target, have the enhanced ability to fix complement and efficiently form immune complexes therefore being considered as vaccine adjuvants (75, 76). A recombinant monoclonal IgM generated with the heavy and light chain variable region from an IgG1 Nab prevented transmission of SHIV in mucosally challenged rhesus macaques (77). However, potentially short half-life, dependence on targeting protruding epitopes due to the conformation and size of IgMs and lack of capacity to induce noncomplement $\mathrm{Fc}$-mediated functions are possible obstacles that need to be overcome. Secretory $\operatorname{IgA}$ (SIgA) plays a critical role in mucosal immunity and appear obvious as isotype for strategies aimed at preventing infection at mucosal surfaces. Indeed, mucosal SIgA have been suggested to be associated with enhanced protection against vaginally transmitted infections including HIV-1 $(78,79)$ and influenza (80) but vaccine induced IgA responses have also been associated with increased risk of infection during the RV144 vaccine trial (81). However, a recent net-work analysis suggested that IgA responses were unlikely to cause impaired humoral immune protection but rather indicated an overall miscoordinated and therefore less functional humoral immune response (82). A study using rectally applied IgA1 resulted in higher level of protection against transmitted SHIV in the NHP model (83). Crosslinking of FcaRI by IgA-immune complexes yields potent neutrophil activation and pro-inflammatory effector functions, including the recruitment of neutrophils (reviewed in (84). If intravenous administration of IgAs will result in protective levels of neutralizing and/or functional SIgA at the mucosal surface needs to be determined. In addition to the engineering of bi-or tri-specific antibodies, e.g. as discussed before, some groups have pursued the targeting of the conserved CD4-binding, and coreceptor-binding sites $(85,86)$, e.g. eCD4-Ig (87), showed exceptional neutralization breadth against most tested HIV-1 strains, regardless of clade or coreceptor preference, including strains resistant to some of the CD4-binding site antibodies like VRC01 and 3BNC117 but also showing activity against SIV and HIV-2 strains. Delivered via a recombinant adeno-associated virus (rAAV), rhesus macaques expressed rh-eCD4-Ig levels and were protected against SHIVAD8 challenges that infected all control animals (87). 


\section{Conclusions}

Until a protective vaccine is available, passive immunization strategies using broadly neutralizing antibodies could be a promising alternative to prevent acquisition of HIV-1 infection. While other long-acting prevention methods, in addition to bNAbs, are also being developed, including sustained-release antiretrovirals, encouraging results from animal protection models support the development of bNAbs for prevention and an increasing number of antibodies with exceptional breadth and potency have been and are getting identified. Further optimization of viral coverage by combining bNAbs with complementary epitope specificities, or by generating multi-specific antibodies, in addition to enhancing $\mathrm{bNAb}$ effector function by Fc engineering and extending antibody half-life in serum will accelerate the clinical implementation of bNAbs as a critical tool for HIV-1 prevention strategies.

\section{Financial support and sponsorship}

This work was supported by NIH grants AI106408 (B.J.) and OD024917, AI126603, AI124377, AI128751, AI129797 (D.H.B.).

\section{Reference}

1. Walker LM, Phogat SK, Chan-Hui PY, Wagner D, Phung P, Goss JL, et al. Broad and potent neutralizing antibodies from an African donor reveal a new HIV-1 vaccine target. Science. 2009;326(5950):285-9. [PubMed: 19729618]

2. Wu X, Yang ZY, Li Y, Hogerkorp CM, Schief WR, Seaman MS, et al. Rational design of envelope identifies broadly neutralizing human monoclonal antibodies to HIV-1. Science.

2010;329(5993):856-61. [PubMed: 20616233]

3. Walker LM, Huber M, Doores KJ, Falkowska E, Pejchal R, Julien JP, et al. Broad neutralization coverage of HIV by multiple highly potent antibodies. Nature. 2011;477(7365):466-70. [PubMed: 21849977]

4. Scheid JF, Mouquet H, Feldhahn N, Seaman MS, Velinzon K, Pietzsch J, et al. Broad diversity of neutralizing antibodies isolated from memory B cells in HIV-infected individuals. Nature. 2009;458(7238):636-40. [PubMed: 19287373]

5. Burton DR, Mascola JR. Antibody responses to envelope glycoproteins in HIV-1 infection. Nature immunology. 2015;16(6):571-6. [PubMed: 25988889]

6. Sok D, Burton DR. Recent progress in broadly neutralizing antibodies to HIV. Nature immunology. 2018;19(11):1179-88. [PubMed: 30333615]

7. Scheid JF, Mouquet H, Ueberheide B, Diskin R, Klein F, Oliveira TY, et al. Sequence and structural convergence of broad and potent HIV antibodies that mimic CD4 binding. Science. 2011;333(6049):1633-7. [PubMed: 21764753]

8. Huang J, Kang BH, Ishida E, Zhou T, Griesman T, Sheng Z, et al. Identification of a CD4-BindingSite Antibody to HIV that Evolved Near-Pan Neutralization Breadth. Immunity. 2016;45(5):110821. [PubMed: 27851912]

9. Rudicell RS, Kwon YD, Ko SY, Pegu A, Louder MK, Georgiev IS, et al. Enhanced potency of a broadly neutralizing HIV-1 antibody in vitro improves protection against lentiviral infection in vivo. Journal of virology. 2014;88(21):12669-82. [PubMed: 25142607]

10. Sok D, Pauthner M, Briney B, Lee JH, Saye-Francisco KL, Hsueh J, et al. A Prominent Site of Antibody Vulnerability on HIV Envelope Incorporates a Motif Associated with CCR5 Binding and Its Camouflaging Glycans. Immunity. 2016;45(1):31-45. [PubMed: 27438765]

11. Doria-Rose NA, Bhiman JN, Roark RS, Schramm CA, Gorman J, Chuang GY, et al. New Member of the V1V2-Directed CAP256-VRC26 Lineage That Shows Increased Breadth and Exceptional Potency. Journal of virology. 2016;90(1):76-91. [PubMed: 26468542] 
12. Mouquet H, Scharf L, Euler Z, Liu Y, Eden C, Scheid JF, et al. Complex-type N-glycan recognition by potent broadly neutralizing HIV antibodies. Proceedings of the National Academy of Sciences of the United States of America. 2012;109(47):E3268-77. [PubMed: 23115339]

13. Trkola A, Purtscher M, Muster T, Ballaun C, Buchacher A, Sullivan N, et al. Human monoclonal antibody 2G12 defines a distinctive neutralization epitope on the gp120 glycoprotein of human immunodeficiency virus type 1. Journal of virology. 1996;70(2):1100-8. [PubMed: 8551569]

14. Huang J, Ofek G, Laub L, Louder MK, Doria-Rose NA, Longo NS, et al. Broad and potent neutralization of HIV-1 by a gp41-specific human antibody. Nature. 2012;491(7424):406-12. [PubMed: 23151583]

15. Falkowska E, Le KM, Ramos A, Doores KJ, Lee JH, Blattner C, et al. Broadly neutralizing HIV antibodies define a glycan-dependent epitope on the prefusion conformation of gp41 on cleaved envelope trimers. Immunity. 2014;40(5):657-68. [PubMed: 24768347]

16. Huang J, Kang BH, Pancera M, Lee JH, Tong T, Feng Y, et al. Broad and potent HIV-1 neutralization by a human antibody that binds the gp41-gp120 interface. Nature. 2014;515(7525):138-42. [PubMed: 25186731]

17. Hessell AJ, Poignard P, Hunter M, Hangartner L, Tehrani DM, Bleeker WK, et al. Effective, lowtiter antibody protection against low-dose repeated mucosal SHIV challenge in macaques. Nature medicine. 2009;15(8):951-4.

18. Hessell AJ, Rakasz EG, Poignard P, Hangartner L, Landucci G, Forthal DN, et al. Broadly neutralizing human anti-HIV antibody 2 G12 is effective in protection against mucosal SHIV challenge even at low serum neutralizing titers. PLoS pathogens. 2009;5(5):e1000433. [PubMed: 19436712]

19. Mascola JR, Stiegler G, VanCott TC, Katinger H, Carpenter CB, Hanson CE, et al. Protection of macaques against vaginal transmission of a pathogenic HIV-1/SIV chimeric virus by passive infusion of neutralizing antibodies. Nature medicine. 2000;6(2):207-10.

20. Shingai M, Donau OK, Plishka RJ, Buckler-White A, Mascola JR, Nabel GJ, et al. Passive transfer of modest titers of potent and broadly neutralizing anti-HIV monoclonal antibodies block SHIV infection in macaques. The Journal of experimental medicine. 2014;211(10):2061-74. [PubMed: 25155019]

21. Pegu A, Yang ZY, Boyington JC, Wu L, Ko SY, Schmidt SD, et al. Neutralizing antibodies to HIV-1 envelope protect more effectively in vivo than those to the CD4 receptor. Science translational medicine. 2014;6(243):243ra88.

22. Baba TW, Liska V, Hofmann-Lehmann R, Vlasak J, Xu W, Ayehunie S, et al. Human neutralizing monoclonal antibodies of the IgG1 subtype protect against mucosal simian-human immunodeficiency virus infection. Nature medicine. 2000;6(2):200-6.

23. Moldt B, Rakasz EG, Schultz N, Chan-Hui PY, Swiderek K, Weisgrau KL, et al. Highly potent HIV-specific antibody neutralization in vitro translates into effective protection against mucosal SHIV challenge in vivo. Proceedings of the National Academy of Sciences of the United States of America. 2012;109(46):18921-5. [PubMed: 23100539]

24. Gautam R, Nishimura Y, Pegu A, Nason MC, Klein F, Gazumyan A, et al. A single injection of anti-HIV-1 antibodies protects against repeated SHIV challenges. Nature. 2016;533(7601):105-9. [PubMed: 27120156]

25. Julg B, Tartaglia LJ, Keele BF, Wagh K, Pegu A, Sok D, et al. Broadly neutralizing antibodies targeting the HIV-1 envelope V2 apex confer protection against a clade C SHIV challenge. Science translational medicine. 2017;9(406).

26. Li H, Wang S, Kong R, Ding W, Lee FH, Parker Z, et al. Envelope residue 375 substitutions in simian-human immunodeficiency viruses enhance CD4 binding and replication in rhesus macaques. Proceedings of the National Academy of Sciences of the United States of America. 2016;113(24):E3413-22. [PubMed: 27247400]

27. Tartaglia LJ, Chang HW, Lee BC, Abbink P, Ng'ang'a D, Boyd M, et al. Production of Mucosally Transmissible SHIV Challenge Stocks from HIV-1 Circulating Recombinant Form 01_AE env Sequences. PLoS pathogens. 2016;12(2):e1005431. [PubMed: 26849216] 
28. Chang HW, Tartaglia LJ, Whitney JB, Lim SY, Sanisetty S, Lavine CL, et al. Generation and evaluation of clade $\mathrm{C}$ simian-human immunodeficiency virus challenge stocks. Journal of virology. 2015;89(4):1965-74. [PubMed: 25473043]

29. Gauduin MC, Parren PW, Weir R, Barbas CF, Burton DR, Koup RA. Passive immunization with a human monoclonal antibody protects hu-PBL-SCID mice against challenge by primary isolates of HIV-1. Nature medicine. 1997;3(12):1389-93.

30. Deruaz M, Moldt B, Le KM, Power KA, Vrbanac VD, Tanno S, et al. Protection of Humanized Mice From Repeated Intravaginal HIV Challenge by Passive Immunization: A Model for Studying the Efficacy of Neutralizing Antibodies In Vivo. The Journal of infectious diseases. 2016;214(4):612-6. [PubMed: 27357340]

31. Sun M, Li Y, Yuan Z, Lu W, Kang G, Fan W, et al. VRC01 antibody protects against vaginal and rectal transmission of human immunodeficiency virus 1 in hu-BLT mice. Arch Virol. 2016;161(9):2449-55. [PubMed: 27343044]

32. Masse-Ranson G, Mouquet H, Di Santo JP. Humanized mouse models to study pathophysiology and treatment of HIV infection. Current opinion in HIV and AIDS. 2018;13(2):143-51. [PubMed: 29194124]

33. Bardhi A, Wu Y, Chen W, Li W, Zhu Z, Zheng JH, et al. Potent In Vivo NK Cell-Mediated Elimination of HIV-1-Infected Cells Mobilized by a gp120-Bispecific and Hexavalent Broadly Neutralizing Fusion Protein. Journal of virology. 2017;91(20).

34. Bournazos S, Klein F, Pietzsch J, Seaman MS, Nussenzweig MC, Ravetch JV. Broadly neutralizing anti-HIV-1 antibodies require Fc effector functions for in vivo activity. Cell. 2014;158(6):1243-53. [PubMed: 25215485]

35. Lu CL, Murakowski DK, Bournazos S, Schoofs T, Sarkar D, Halper-Stromberg A, et al. Enhanced clearance of HIV-1-infected cells by broadly neutralizing antibodies against HIV-1 in vivo. Science. 2016;352(6288):1001-4. [PubMed: 27199430]

36. Flerin NC, Bardhi A, Zheng JH, Korom M, Folkvord J, Kovacs C, et al. Establishment of A Novel Humanized Mouse Model To Investigate In Vivo Activation and Depletion of Patient-Derived HIV Latent Reservoirs. Journal of virology. 2019.

37. Wagh K, Bhattacharya T, Williamson C, Robles A, Bayne M, Garrity J, et al. Optimal Combinations of Broadly Neutralizing Antibodies for Prevention and Treatment of HIV-1 Clade C Infection. PLoS pathogens. 2016;12(3):e1005520. [PubMed: 27028935]

38. Julg B, Liu PT, Wagh K, Fischer WM, Abbink P, Mercado NB, et al. Protection against a mixed SHIV challenge by a broadly neutralizing antibody cocktail. Science translational medicine. 2017;9(408).

39. Huang Y, Yu J, Lanzi A, Yao X, Andrews CD, Tsai L, et al. Engineered Bispecific Antibodies with Exquisite HIV-1-Neutralizing Activity. Cell. 2016;165(7):1621-31. [PubMed: 27315479]

40. Xu L, Pegu A, Rao E, Doria-Rose N, Beninga J, McKee K, et al. Trispecific broadly neutralizing HIV antibodies mediate potent SHIV protection in macaques. Science. 2017;358(6359):85-90. [PubMed: 28931639]

41. Kong R, Louder MK, Wagh K, Bailer RT, deCamp A, Greene K, et al. Improving neutralization potency and breadth by combining broadly reactive HIV-1 antibodies targeting major neutralization epitopes. Journal of virology. 2015;89(5):2659-71. [PubMed: 25520506]

42. Caskey M, Schoofs T, Gruell H, Settler A, Karagounis T, Kreider EF, et al. Antibody 10-1074 suppresses viremia in HIV-1-infected individuals. Nature medicine. 2017;23(2):185-91.

43. Ledgerwood JE, Coates EE, Yamshchikov G, Saunders JG, Holman L, Enama ME, et al. Safety, pharmacokinetics and neutralization of the broadly neutralizing HIV-1 human monoclonal antibody VRC01 in healthy adults. Clin Exp Immunol. 2015;182(3):289-301. [PubMed: 26332605]

44. Lynch RM, Boritz E, Coates EE, DeZure A, Madden P, Costner P, et al. Virologic effects of broadly neutralizing antibody VRC01 administration during chronic HIV-1 infection. Science translational medicine. 2015;7(319):319ra206.

45. Caskey M, Klein F, Lorenzi JC, Seaman MS, West AP, Jr., Buckley N, et al. Viraemia suppressed in HIV-1-infected humans by broadly neutralizing antibody 3BNC117. Nature.

2015;522(7557):487-91. [PubMed: 25855300] 
46. Bar-On Y, Gruell H, Schoofs T, Pai JA, Nogueira L, Butler AL, et al. Safety and antiviral activity of combination HIV-1 broadly neutralizing antibodies in viremic individuals. Nature medicine. 2018;24(11):1701-7.

47. Pegu A, Hessell AJ, Mascola JR, Haigwood NL. Use of broadly neutralizing antibodies for HIV-1 prevention. Immunol Rev. 2017;275(1):296-312. [PubMed: 28133803]

48. Zalevsky J, Chamberlain AK, Horton HM, Karki S, Leung IW, Sproule TJ, et al. Enhanced antibody half-life improves in vivo activity. Nature biotechnology. 2010;28(2):157-9.

49. Ko SY, Pegu A, Rudicell RS, Yang ZY, Joyce MG, Chen X, et al. Enhanced neonatal Fc receptor function improves protection against primate SHIV infection. Nature. 2014;514(7524):642-5. [PubMed: 25119033]

50. Gautam R, Nishimura Y, Gaughan N, Gazumyan A, Schoofs T, Buckler-White A, et al. A single injection of crystallizable fragment domain-modified antibodies elicits durable protection from SHIV infection. Nature medicine. 2018;24(5):610-6.

51. Hessell AJ, Jaworski JP, Epson E, Matsuda K, Pandey S, Kahl C, et al. Early short-term treatment with neutralizing human monoclonal antibodies halts SHIV infection in infant macaques. Nature medicine. 2016;22(4):362-8.

52. Liu J, Ghneim K, Sok D, Bosche WJ, Li Y, Chipriano E, et al. Antibody-mediated protection against SHIV challenge includes systemic clearance of distal virus. Science. 2016.

53. Stefic K, Chaillon A, Bouvin-Pley M, Moreau A, Braibant M, Bastides F, et al. Probing the compartmentalization of HIV-1 in the central nervous system through its neutralization properties. PloS one. 2017;12(8):e0181680. [PubMed: 28841647]

54. Santra S, Tomaras GD, Warrier R, Nicely NI, Liao HX, Pollara J, et al. Human Non-neutralizing HIV-1 Envelope Monoclonal Antibodies Limit the Number of Founder Viruses during SHIV Mucosal Infection in Rhesus Macaques. PLoS pathogens. 2015;11(8):e1005042. [PubMed: 26237403]

55. Moog C, Dereuddre-Bosquet N, Teillaud JL, Biedma ME, Holl V, Van Ham G, et al. Protective effect of vaginal application of neutralizing and nonneutralizing inhibitory antibodies against vaginal SHIV challenge in macaques. Mucosal Immunol. 2014;7(1):46-56. [PubMed: 23591718]

56. Sun Y, Asmal M, Lane S, Permar SR, Schmidt SD, Mascola JR, et al. Antibody-dependent cellmediated cytotoxicity in simian immunodeficiency virus-infected rhesus monkeys. Journal of virology. 2011;85(14):6906-12. [PubMed: 21593181]

57. Asmal M, Sun Y, Lane S, Yeh W, Schmidt SD, Mascola JR, et al. Antibody-dependent cellmediated viral inhibition emerges after simian immunodeficiency virus SIVmac251 infection of rhesus monkeys coincident with gp140-binding antibodies and is effective against neutralizationresistant viruses. Journal of virology. 2011;85(11):5465-75. [PubMed: 21450829]

58. Hessell AJ, Hangartner L, Hunter M, Havenith CE, Beurskens FJ, Bakker JM, et al. Fc receptor but not complement binding is important in antibody protection against HIV. Nature. 2007;449(7158):101-4. [PubMed: 17805298]

59. Chung AW, Navis M, Isitman G, Wren L, Silvers J, Amin J, et al. Activation of NK cells by ADCC antibodies and HIV disease progression. Journal of acquired immune deficiency syndromes. 2011;58(2):127-31. [PubMed: 21792067]

60. Lambotte O, Pollara J, Boufassa F, Moog C, Venet A, Haynes BF, et al. High antibody-dependent cellular cytotoxicity responses are correlated with strong CD8 T cell viral suppressive activity but not with B57 status in HIV-1 elite controllers. PloS one. 2013;8(9):e74855. [PubMed: 24086385]

61. Ackerman ME, Mikhailova A, Brown EP, Dowell KG, Walker BD, Bailey-Kellogg C, et al. Polyfunctional HIV-Specific Antibody Responses Are Associated with Spontaneous HIV Control. PLoS pathogens. 2016;12(1):e1005315. [PubMed: 26745376]

62. Dugast AS, Chan Y, Hoffner M, Licht A, Nkolola J, Li H, et al. Lack of protection following passive transfer of polyclonal highly functional low-dose non-neutralizing antibodies. PloS one. 2014;9(5):e97229. [PubMed: 24820481]

63. Sips M, Krykbaeva M, Diefenbach TJ, Ghebremichael M, Bowman BA, Dugast AS, et al. Fc receptor-mediated phagocytosis in tissues as a potent mechanism for preventive and therapeutic HIV vaccine strategies. Mucosal Immunol. 2016;9(6):1584-95. [PubMed: 26883728] 
64. Boesch AW, Brown EP, Ackerman ME. The role of Fc receptors in HIV prevention and therapy. Immunol Rev. 2015;268(1):296-310. [PubMed: 26497529]

65. Yasmeen A, Ringe R, Derking R, Cupo A, Julien JP, Burton DR, et al. Differential binding of neutralizing and non-neutralizing antibodies to native-like soluble HIV-1 Env trimers, uncleaved Env proteins, and monomeric subunits. Retrovirology. 2014;11:41. [PubMed: 24884783]

66. Bruel T, Guivel-Benhassine F, Lorin V, Lortat-Jacob H, Baleux F, Bourdic K, et al. Lack of ADCC Breadth of Human Nonneutralizing Anti-HIV-1 Antibodies. Journal of virology. 2017;91(8).

67. Bournazos S, Ravetch JV. Anti-retroviral antibody FcgammaR-mediated effector functions. Immunol Rev. 2017;275(1):285-95. [PubMed: 28133801]

68. Michaud HA, Gomard T, Gros L, Thiolon K, Nasser R, Jacquet C, et al. A crucial role for infectedcell/antibody immune complexes in the enhancement of endogenous antiviral immunity by short passive immunotherapy. PLoS pathogens. 2010;6(6):e1000948. [PubMed: 20548955]

69. Schoofs T, Klein F, Braunschweig M, Kreider EF, Feldmann A, Nogueira L, et al. HIV-1 therapy with monoclonal antibody 3BNC117 elicits host immune responses against HIV-1. Science. 2016;352(6288):997-1001. [PubMed: 27199429]

70. Haigwood NL, Montefiori DC, Sutton WF, McClure J, Watson AJ, Voss G, et al. Passive immunotherapy in simian immunodeficiency virus-infected macaques accelerates the development of neutralizing antibodies. Journal of virology. 2004;78(11):5983-95. [PubMed: 15140996]

71. Ng CT, Jaworski JP, Jayaraman P, Sutton WF, Delio P, Kuller L, et al. Passive neutralizing antibody controls SHIV viremia and enhances B cell responses in infant macaques. Nature medicine. 2010;16(10):1117-9.

72. Nishimura Y, Gautam R, Chun TW, Sadjadpour R, Foulds KE, Shingai M, et al. Early antibody therapy can induce long-lasting immunity to SHIV. Nature. 2017;543(7646):559-63. [PubMed: 28289286]

73. Julg B, Pegu A, Abbink P, Liu J, Brinkman A, Molloy K, et al. Virological Control by the CD4Binding Site Antibody N6 in Simian-Human Immunodeficiency Virus-Infected Rhesus Monkeys. Journal of virology. 2017;91(16).

74. Scheid JF, Horwitz JA, Bar-On Y, Kreider EF, Lu CL, Lorenzi JC, et al. HIV-1 antibody 3BNC117 suppresses viral rebound in humans during treatment interruption. Nature. 2016;535(7613):55660. [PubMed: 27338952]

75. Dunkelberger JR, Song WC. Complement and its role in innate and adaptive immune responses. Cell Res. 2010;20(1):34-50. [PubMed: 20010915]

76. Racine R, Winslow GM. IgM in microbial infections: taken for granted? Immunology letters. 2009;125(2):79-85. [PubMed: 19539648]

77. Gong S, Tomusange K, Kulkarni V, Adeniji OS, Lakhashe SK, Hariraju D, et al. Anti-HIV IgM protects against mucosal SHIV transmission. Aids. 2018;32(11):F5-F13. [PubMed: 29762161]

78. Choi RY, Levinson P, Guthrie BL, Lohman-Payne B, Bosire R, Liu AY, et al. Cervicovaginal HIV-1-neutralizing immunoglobulin A detected among HIV-1-exposed seronegative female partners in HIV-1-discordant couples. Aids. 2012;26(17):2155-63. [PubMed: 22948273]

79. Hirbod T, Kaul R, Reichard C, Kimani J, Ngugi E, Bwayo JJ, et al. HIV-neutralizing immunoglobulin A and HIV-specific proliferation are independently associated with reduced HIV acquisition in Kenyan sex workers. Aids. 2008;22(6):727-35. [PubMed: 18356602]

80. Gould VMW, Francis JN, Anderson KJ, Georges B, Cope AV, Tregoning JS. Nasal IgA Provides Protection against Human Influenza Challenge in Volunteers with Low Serum Influenza Antibody Titre. Front Microbiol. 2017;8:900. [PubMed: 28567036]

81. Haynes BF, Gilbert PB, McElrath MJ, Zolla-Pazner S, Tomaras GD, Alam SM, et al. Immunecorrelates analysis of an HIV-1 vaccine efficacy trial. The New England journal of medicine. 2012;366(14):1275-86. [PubMed: 22475592]

82. Chung AW, Kumar MP, Arnold KB, Yu WH, Schoen MK, Dunphy LJ, et al. Dissecting Polyclonal Vaccine-Induced Humoral Immunity against HIV Using Systems Serology. Cell. 2015;163(4):988-98. [PubMed: 26544943]

83. Watkins JD, Sholukh AM, Mukhtar MM, Siddappa NB, Lakhashe SK, Kim M, et al. Anti-HIV IgA isotypes: differential virion capture and inhibition of transcytosis are linked to prevention of mucosal R5 SHIV transmission. Aids. 2013;27(9):F13-20. [PubMed: 23775002] 
84. Heineke MH, van Egmond M. Immunoglobulin A: magic bullet or Trojan horse? Eur J Clin Invest. 2017;47(2):184-92. [PubMed: 28024097]

85. Chen W, Feng Y, Prabakaran P, Ying T, Wang Y, Sun J, et al. Exceptionally potent and broadly cross-reactive, bispecific multivalent HIV-1 inhibitors based on single human CD4 and antibody domains. Journal of virology. 2014;88(2):1125-39. [PubMed: 24198429]

86. Sun M, Pace CS, Yao X, Yu F, Padte NN, Huang Y, et al. Rational design and characterization of the novel, broad and potent bispecific HIV-1 neutralizing antibody iMabm36. Journal of acquired immune deficiency syndromes. 2014;66(5):473-83. [PubMed: 24853313]

87. Gardner MR, Kattenhorn LM, Kondur HR, von Schaewen M, Dorfman T, Chiang JJ, et al. AAVexpressed eCD4-Ig provides durable protection from multiple SHIV challenges. Nature.

2015;519(7541):87-91. [PubMed: 25707797] 


\section{Key bullet points}

1. New-generation broadly neutralizing antibodies (bNAbs) with remarkable potency and breadth have been identified.

2. Passive transfer of bNAbs results in potent protection against infection in preclinical animal models.

3. bNAbs have demonstrated favorable safety profiles and robust antiviral activity in chronically infected individuals.

4. Given the global diversity of HIV-1, bNAb combinations or multi-specific antibodies will most likely be required to produce the necessary breadth for effective protection. 
Table 1.

Target sites on the HIV-1 envelope trimer and exemplary bNAbs

\begin{tabular}{llll}
\hline Target site & Antibody & Clinical Development & Reference \\
\hline CD4-binding site & VRC01, 3BNC117, N6, VRC07-523 & Yes & $(2,7-9)$ \\
\hline V2-glycan site & PG9, PGDM1400 and CAP256-VRC26.25 & Yes & $(1,10,11)$ \\
\hline V3-glycan site & PGT121 and 10-1074 & Yes & $(3,12)$ \\
\hline Glycan epitope on the outer domain of gp120 & $2 \mathrm{G} 12$ & No & $(13)$ \\
\hline Membrane-proximal external region (MPER) & $10 \mathrm{E} 8$ & Yes & $(14)$ \\
\hline Interface region between gp120 and gp41 & $35 \mathrm{O} 22$ and PGT151 & No & $(15,16)$ \\
\hline
\end{tabular}

